4 Colucci M, Paramo JA, Collen D. Generation in plasma of a fast-acting inhibitor of plasminogen activator in response to endotoxin stimulation. $\mathcal{F}$ Clin Inves 1985;75:818-24

5 Willems PL, Piessens J. Implementation and experience with a computer based coronary artery reporting and information system. In: Ostrow HG, Ripley KL, eds. Computers in cardiology. Long Beach: Institute of Electrical and Electronic Engineers, Computer Society Press, 1977:465-70.

(Accepted 16 May 1985)

Centre for Thrombosis and Vascular Research, Campus Gasthuis-

berg, University of Leuven, B-3000 Leuven, Belgium

A PARAMO, MD, research fellow

$M$ COLUCCI, MS, research fellow

D COLLEN, MD, PHD, professor of medicine

Division of Cardiology, University of Leuven

F VAN DE WERF, MD, PHD, professor of medicine

Correspondence to: Dr Collen.

\section{Plasma testosterone concentrations in asthmatic men treated with glucocorticoids}

Patients receiving pharmacological doses of glucocorticoids may develop several complications secondary to the drugs' catabolic effects on bone, muscle, and skin. Hypogonadism may induce similar changes and contribute to the damage induced by glucocorticoids as plasma testosterone concentrations in men are suppressed by the acute administration of glucocorticoids. ${ }^{1}$ There is, however, no information on pituitary and gonadal function in men who are treated with long term glucocorticoids. We examined this issue in asthmatic patients dependent on steroids.

\section{Patients, methods, and results}

Eleven asthmatic men requiring continuous treatment with prednisone in daily doses greater than $7.5 \mathrm{mg}$ were matched by age with asthmatic patients who were not receiving glucocorticoids. The mean (SEM) prednisone dose was $17.6(2.9) \mathrm{mg} /$ day and the mean (SEM) duration of treatmen $6.9(1.8)$ years. The mean ages of patients in the glucocorticoid and control groups were 55.4 years (range $24-74$ ) and 54.7 years (range $21-77$ ), respectively. All subjects were studied in the outpatient clinic and were free from acute symptoms of asthma. Blood samples were taken mid-morning for measurement of total testosterone, dehydroepiandrosterone sulphate, sex hormone binding globulin, follicle stimulating hormone, and luteinising hormone concentrations. Blood for measurement of zinc concentrations was drawn, with minimal venostasis, into plastic tubes containing heparin free from zinc.

Testosterone and dehydroepiandrosterone sulphate concentrations were measured by in house radioimmunoassays with highly specific antisera and gonadotrophins by Amerlex RIA kits. Sex hormone binding globulin concentration was measured by the method of Rudd $e t a l^{2}$ and used, with total testosterone concentrations, to derive plasma free testosterone concentration. Plasma zinc concentration was measured by atomic absorption spectrometry. Comparisons were made with the Student's $t$ test for paired data.

Mean values for plasma total and free testosterone concentrations in the

Plasma biochemical variables of asthmatic men treated with glucocorticoids and matched for age asthmatic controls. Values are means (SEM) (and normal ranges)

\begin{tabular}{|c|c|c|c|}
\hline & \multicolumn{2}{|c|}{ Treatment group } & \multirow[b]{2}{*}{$\mathrm{p}$ Value } \\
\hline & $\begin{array}{l}\text { Control } \\
(\mathrm{n}=11)\end{array}$ & $\begin{array}{l}\text { Glucocorticoid } \\
(\mathrm{n}=11)\end{array}$ & \\
\hline Total testosterone $(\mathrm{nmol} / \mathrm{l})$ & $19 \cdot 4(1 \cdot 2)$ & $12 \cdot 2(1 \cdot 7)$ & $<0.01$ \\
\hline Sex hormone binding globulin $(\mathrm{nmol} / \mathrm{l})$ & $54 \cdot 9(2 \cdot 7)$ & $\begin{array}{l}53 \cdot 6(2 \cdot 2) \\
.65)\end{array}$ & NS \\
\hline Calculated free testosterone ( $\mathrm{pmol} / \mathrm{l})$ & $578(54)$ & $340(49)$ & $<0.01$ \\
\hline Follicle stimulating hormone $(\mathrm{mIU} / \mathrm{ml})$ & $6.5(0.9)$ & $(1-9)^{9 \cdot 9(1 \cdot 2)}$ & $<0.02$ \\
\hline Luteinising hormone $(\mathrm{mIU} / \mathrm{ml})$ & $8 \cdot 2(1 \cdot 1)$ & $\begin{array}{l}16 \cdot 5(3 \cdot 6) \\
(2-12)\end{array}$ & $<0.05$ \\
\hline Dehydroepiandrosterone sulphate $(\mu \mathrm{mol} / \mathrm{l})$ & $3 \cdot 2(1 \cdot 1)$ & $0.9(0.2)$ & $<0.05$ \\
\hline Zinc $^{*}(\mu \mathrm{mol} / \mathrm{l})$ & $11.6(0.3)$ & $(12-20)(0 \cdot 5)$ & NS \\
\hline
\end{tabular}

* Measured in 10 pairs of subjects only.

* Measured in 10 pairs of subjects only.
Conversion: SI to traditional units-Testosterone: $1 \mathrm{nmol} / 1 \approx 0.3 \mathrm{ng} / \mathrm{ml}$. De-
hydroepiandrosterone sulphate: $1 \mu \mathrm{mol} / 1 \approx 0.367 \mu \mathrm{g} / \mathrm{ml}$. Zinc: $1 \mu \mathrm{mol} / 1 \approx 0.07 \mathrm{mg} / \mathrm{l}$. patients treated with glucocorticoids were roughly $60 \%$ of those in the control group, and in six patients the concentrations of both were below the normal range (table). In the glucocorticoid group the mean dehydroepiandrosterone sulphate concentration was $26 \%$ of that of the control group, and plasma follicle stimulating hormone and luteinising hormone concentrations were higher by $52 \%$ and $100 \%$, respectively. Plasma zinc concentrations did not differ between the groups.

\section{Comment}

These data show that long term administration of prednisone to asthmatic men suppresses plasma testosterone concentrations. The raised plasma follicle stimulating hormone and luteinising hormone concentrations indicate an appropriate pituitary response and suggest either a direct action of the glucocorticoid on synthesis of testosterone or a reduction in the supply of substrate, such as adrenal dehydroepiandrosterone, to the testis. A direct action on the testis seems more probable as the increase in plasma cortisol concentration that follows administration of corticotrophin is also accompanied by a decrease in plasma testosterone concentration. ${ }^{11}$

The nature of the testicular defect is unclear. Deficiency in zinc has been described in asthmatic patients treated with glucocorticoids ${ }^{3}$ and is a recognised cause of hypogonadism. This is unlikely to be the mechanism in our study as plasma zinc concentrations were the same in each group. Studies in rats have suggested that glucocorticoids may reduce the number of gonadotrophin binding sites on testicular cells, ${ }^{4}$ and our data are consistent with such a mechanism.

In men testosterone is thought to promote formation of bone, inhibit resorption of bone, and thus lead to positive balance of calcium. ${ }^{5}$ The major reduction in plasma testosterone concentration seen in these patients might therefore contribute appreciably to the development of osteoporosis and also to the soft tissue atrophy associated with the use of glucocorticoids. As established osteoporosis induced by glucocorticoids is a difficult clinical problem plasma testosterone concentrations should be measured in all men receiving long term treatment with glucocorticoids and replacement treatment given if low concentrations are found.

We acknowledge the secretarial help of Mrs E Bambury and the technical help of the staff of the Hormone Assay Laboratory, National Women's Hospital, Auckland.

Schaison G, Durand F, Mowszowicz I. Effect of glucocorticoids on plasma testosterone in men Acta Endocrinol 1978;89:126-31.

Rudd BT, Duignan NM, Lndon DR A rapid method for the measurement of sex hormone binding globulin capacity of sera. Clin Chim Acta 1974;55:165-78. Ellul-Micallef R, Galdes A, Fenech FF. Serum zinc levels in corticosteroid-treated asthmatic patients. Postgrad Med $\mathcal{F} 1976 ; 52: 148-50$.

Saez JM, Morera AM, Haour F, Evain D. Effects of in vivo administration of dexamethasone, corticotropin and human chorionic gonadotropin on steroidogenesis and protein and DNA synthesis of testicular interstitial cells in prepuberal rats. Endocrinology 1977;101:1256-63

Defects of sex steroid

Accepted 21 May 1985)

Section of Endocrinology, Department of Medicine, University of Auckland, Auckland, New Zealand

I R REID, $M B$, $\mathrm{CHB}$, research fellow

H K IBBERTSON, FRCP, FRACP, professor

Postgraduate School of Obstetrics and Gynaecology, National Women's Hospital, Auckland, New Zealand

J T FRANCE, PHD, FAACB, associate professor

Department of Clinical Chemistry, Auckland Hospital, Auckland, New Zealand

J PYBUS, FNZIC, senior scientific officer

Correspondence to: Dr I R Reid, Division of Bone and Mineral Metabolism, Department of Medicine, Jewish Hospital of St Louis, PO Box 14109, St Louis, Missouri 63178, United States of America.

\section{Correction}

Importance of hypovolaemic shock and endoscopic signs in predicting recurrent haemorrhage from peptic ulceration: a prospective evaluation

Three errors occurred in this paper by P C Bornman et al (27 July, p 245). In table I the number of rebleeds in patients with endoscopic signs of a clot should have read 12 (25) not 11 (23). In table II the value 112 under "No endoscopic sign, black spots" should have read 86 , and the remaining 26 patients should have been tabulated under "Endoscopic sign, no rebleed." 